\title{
Perturbations in the urinary exosome in transplant rejection
}

\section{Tara K. Sigdel ${ }^{1}$, Yolanda W. $\mathrm{Ng}^{1}$, Sangho Lee ${ }^{2}$, Carrie D. Nicora ${ }^{3}$, Wei-Jun Qian ${ }^{3}$, Richard D. Smith $^{3}$, David G. Camp II ${ }^{3}$ and Minnie M. Sarwal ${ }^{1 *}$}

${ }^{1}$ Division of Transplant Surgery, Department of Surgery, University of California San Francisco, San Francisco, CA, USA

${ }^{2}$ Department of Nephrology, Kyung Hee University, Seoul, South Korea

${ }^{3}$ Biological Sciences Division, Pacific Northwest National Laboratory, Richland, WA, USA

\section{Edited by:}

John Cijiang He, Icahn School of Medicine at Mount Sinai, USA

Reviewed by:

Rajeev Rohatgi, Icahn School of Medicine at Mount Sinai, USA

Markus Bitzer, University of Michigan, USA

\section{*Correspondence:}

Minnie M. Sarwal, Division of

Transplant Surgery, Department of

Surgery, University of California San

Francisco, 513 Parnassus Avenue,

S-1269, San Francisco, CA 94143,

USA

e-mail:minnie.sarwal@ucsf.edu
Background: Urine exosomes are small vesicles exocytosed into the urine by all renal epithelial cell types under normal physiologic and disease states. Urine exosomal proteins may mirror disease specific proteome perturbations in kidney injury. Analysis methodologies for the exosomal fraction of the urinary proteome were developed for comparing the urinary exosomal fraction versus unfractionated proteome for biomarker discovery.

Methods: Urine exosomes were isolated by centrifugal filtration of urine samples collected from kidney transplant patients with and without acute rejection (AR), which were biopsy matched. The proteomes of unfractionated whole urine (UW) and urine exosomes (Ue) underwent mass spectroscopy-based quantitative proteomics analysis. The proteome data were analyzed for significant differential protein abundances in AR.

Results: A total of 1018 proteins were identified in Uw and 349 proteins in Ue. Two hundred seventy-nine overlapped between the two urinary compartments and 70 proteins were unique to the Ue compartment. Of 349 exosomal proteins identified from transplant patients, 220 had not been previously identified in the normal Ue fraction. Eleven Ue proteins, functionally involved in an inflammatory and stress response, were more abundant in urine samples from patients with $A R$, three of which are exclusive to the Ue fraction. Ue AR-specific biomarkers (1) were also detected in Uw, but since they were observed at significantly lower abundances in Uw, they were not significant for AR in Uw.

Conclusion: A rapid urinary exosome isolation method and quantitative measurement of enriched Ue proteins was applied. Perturbed proteins in the exosomal compartment of urine collected from kidney transplant patients were specific to inflammatory responses, and were not observed in the Ue fraction from normal healthy subjects. Ue-specific protein alterations in renal disease provide potential mechanistic insights and offer a unique panel of sensitive biomarkers for monitoring AR.

Keywords: urine exosomes, kidney transplant, acute renal allograft rejection, biomarkers, proteomics

\section{INTRODUCTION}

Exosomes are $50-90 \mathrm{~nm}$ vesicles secreted by a wide range of mammalian cell types as a consequence of fusion of multivesicular late endosomes/lysosomes with the plasma membrane $(2,3)$. During the construction of endosomes and intraluminal vesicles (ILVs), specific membrane, and cytosolic proteins are incorporated and secreted in the excretory pathway of exosomes. Therefore, exosomes from different cellular origins contain cell-type specific components that mirror the biological function of the parent cell as well as common molecules, which are needed for their structure and function (4). Recent evidence suggests that exosomes are also involved in the modulation of immune function and dissemination of several infectious cargos such as HIV. Exosomes can also be involved in antigen presentation to T cells (5) and the development of tolerance (6). DC-derived exosomes called dexosomes express high levels of functional MHC class-I and class-II peptide complexes along with CD86 molecules (7). It was also suggested that exosomal RNA could be transferred between cells and represents a new mechanism of gene-based communication between mammalian cells (8). These immune modulating and cell to cell communication properties of exosomes indicate that urine exosomes could be an advantageous source to study the mechanisms of and discover useful biomarkers in variable kidney diseases, including the study of various injury processes in kidney transplantation.

The evolution of current mass spectrometry (MS)-based proteomic approaches have contributed substantially to our understanding of the molecular characterization of urine proteins. However, one of the main hurdles for biomarker discovery with urine proteomics is discerning proteins present at low levels from other highly abundant proteins such as albumin and uromodulin. In addition, the heterogeneity of urine protein added its complexity 
in urine proteomics. The origin of protein in proteinuric patients could be one of the following; first, the filtrate of plasma protein through intact (overflow proteinuria) or damaged glomerular basement membrane or podocyte (glomerulopathy), finally, excretory vesicles (exosomes) or membrane-shed vesicles (microparticles, also referred to as ectosomes) from kidney and uroepithelial cells. In contrast to established proteomic approaches, subproteome approaches which direct to study certain excretory vesicles such as exosomes could be more informative for disease identification and progression, because it could offer the simple way to get rid of the most abundant protein from the unprocessed urine and simplify the source of urine protein, especially for the proteinuric patients.

Amid the early experiments to evaluate the route for the tubular protein in urine, Pisitikun et al. isolated the exosomes from urine with a differential ultracentrifugation method and confirmed the expression of several apical transporter proteins, which originated from renal tubules. More recently, this group analyzed the urine exosomes using liquid chromatography coupled with tandem mass spectrometry (LC-MS/MS) and identified 1132 proteins (2). Other studies to find the biomarkers from specific small vesicles for prostate and bladder cancers were also attempted (3, 4). Miranda et al. also showed human urinary exosomes contained enough mRNA for kidney specific genes (5). Nevertheless, the absence of a standardized protocol for isolating exosomes from clinical specimens and adequate normalization for timed collections are hurdles to the clinical application of urine exosomes. However, recent approaches, which use nanomembrane and microfilter centrifugation to isolate exosome enriched fractions, suggested that urine exosomes could be a reliable source for biomarker discovery and incorporated into the clinical application $(6,7)$. We tested a centrifugal filtration method to isolate exosomes from the urine of kidney transplant recipients. Our result demonstrated that the centrifugal filtration has advantage over the ultracentrifugal method in its simple experimental setup, less time spent in exosomal extraction, and identification of novel exosomal proteins that were not reported by previously published works.

Data are lacking on the regulation of exosomes in physiologic stress and what differences occur in the urine exosomal fraction under various pathologic conditions in kidney transplantation. If the phenotype specific differences could be identified in exosomes from the patients with different transplant-associated renal injuries, subproteomics using exosomes could serve as good complement to current proteomics and genomic approaches for improving on our knowledge on the mechanism and monitoring of renal injury.

In contrast to established proteomic approaches, subproteome approaches which direct to study certain excretory vesicles such as exosomes could be more informative for disease identification and progression, because it could offer a method for biomarker discovery in renal diseases without the confounding influence of abundant proteins found in unprocessed urine.

In this study, we have undertaken a pilot study of 30 urinary samples from renal transplant patients with biopsy proven AR and 20 urine samples from non-AR controls with other forms of renal injuries such as BK nephropathy (BKVN) and chronic allograft injury (CAI). The purpose of the study was to study if phenotype specific differences could be identified in exosomal enrichment fraction in urine from patients specific to biopsy confirmed acute renal transplant rejection.

\section{MATERIALS AND METHODS STUDY POPULATION AND SAMPLES}

A total of 30 mid-stream, second morning void urine samples from kidney transplant patients that included non-acute rejection $(\mathrm{nAR} ; n=20)$ and acute rejection $(\mathrm{AR} ; n=10)$ were selected from a large and highly annotated biobank of urine samples collected from pediatric and young adult recipients of kidney transplants from 2000 to 2009 at Lucile Packard Children's Hospital at Stanford University. The bio-repository consisted of 2000 banked urine samples of which 770 were biopsy matched and collected prior to any treatment intensification for clinical graft dysfunction. "Allograft injury" in this study was defined as a $>20 \%$ increase in serum creatinine from its previous steady-state baseline value and an associated biopsy that was pathological. All biopsies were blindly semi-quantitatively scored by a single pathologist using the most recent Banff criteria for both acute and chronic injury $(1,8-10)$. AR was defined at minimum, as per Banff Schema, a tubulitis score $\geq 1$ accompanied with an interstitial inflammation score $\geq 1, \mathrm{nAR}$ patients were inclusive of patients with CAI and was defined at minimum, as tubular atrophy score $\geq 1$ accompanied by an interstitial fibrosis score $\geq 1$. Also, included were BKVN that was defined by a demonstration of a positive blood BK viral load, graft inflammation, and a positive immunohistochemical stain for the polyoma virus. The patients included in this study were all on a maintenance combination of tacrolimus, mycophenolic acid, and were either on maintenance steroids or on a steroid avoidance protocol (11). The study was approved by the Ethics Committee of Stanford University Medical School and University of California San Francisco, and all patients/guardians provided informed consent to participate in the research, in full adherence to the Declaration of Helsinki. This study was approved by the Institutional Review Board for Human Subjects Research at Pacific Northwest National Laboratory in accordance with federal regulations.

\section{URINE COLLECTION, INITIAL PROCESSING, AND STORAGE}

We used standards recommended by human kidney and urine proteome project (HKUPP) while collecting and processing samples that were applicable in the kidney transplant clinic. Second morning, void, mid-stream urine samples $(50-100 \mathrm{~mL})$ were collected in sterile containers and centrifuged at $2000 \times g$ for $20 \mathrm{~min}$ at room temperature within $1 \mathrm{~h}$ of collection. The supernatant was separated from the pellet containing any particulate matter including cells and cell debris. The $\mathrm{pH}$ of the supernatant was adjusted to 7.0 and stored at $-80^{\circ} \mathrm{C}$ until further analysis. Prior to these proposed studies, we established protocols that allowed for stable urine collection from multicenter clinical studies (12), where delays in storage and processing can occur. With our protocols, urine samples can be safely stored up to $1 \mathrm{~h}$ at room temperature and up to $12 \mathrm{~h}$ at $4^{\circ} \mathrm{C}$ without significant protein degradation; samples do not require addition of protease inhibitors to improve sample integrity if stored at $4^{\circ} \mathrm{C}$ or $-80^{\circ} \mathrm{C}$ within $72 \mathrm{~h}$; and centrifugal filtration was our optimal processing method. In order to ensure minimum impact of freeze thaw cycles, we aliquoted urine 
samples into $10 \mathrm{~mL}$ aliquots (5-10 tubes per sample) prior to freezing, to ensure that multiple assays can be done without multiple freeze thaw cycles. Our assay utilized $10 \mathrm{~mL}$ starting urine so each aliquot only needed to be thawed once for the experiments.

\section{ISOLATION OF PROTEIN FROM WHOLE URINE}

We followed previously published method that was developed in the lab for urine protein isolation (13). Briefly, proteins were isolated by using centrifugal filtration of the supernatant through Amicon Ultra centrifugal filtration tubes (10,000 molecular weight cutoff, Millipore, Bedford, MA, USA). The filter tube was initially washed with $10 \mathrm{~mL}$ of $50 \mathrm{mM} \mathrm{NH}_{4} \mathrm{HCO}_{3}(\mathrm{pH} 8.0)$ and discarded. Then a $10 \mathrm{~mL}$ aliquot of urine was loaded into the device and centrifuged for $20 \mathrm{~min}$ at $3000 \times g$ at $10^{\circ} \mathrm{C}$, and the retentate was used as protein extract for the whole urine.

\section{ISOLATION OF URINE EXOSOMES}

\section{Exosome isolation by ultracentrifugation}

Clarified urine $(10 \mathrm{~mL})$ was centrifuged at $200,000 \times g$ in a fixed angle rotor (45Ti Beckman Instruments) for $110 \mathrm{~min}$. The supernatant was removed and the pellet washed with a large volume of $1 \times$ phosphate buffered saline (PBS) and centrifuged again at $200,000 \times g$ for $110 \mathrm{~min}$. The pellet was re-suspended in isolation buffer ( $10 \mathrm{mM}$ triethanolamine, $250 \mathrm{mM}$ sucrose, $\mathrm{pH} 7.6)$ supplemented with protease inhibitors (Complete Mini) and protein concentration determined using a microBCA assay (Pierce).

\section{Exosome isolation by nanomembrane concentrator}

A $10 \mathrm{~mL}$ volume of urine was thawed and $12.5 \mu \mathrm{L}$ of Protease Inhibitor Cocktail (Sigma-Aldrich P2714; prepared by adding one vial to $5 \mathrm{~mL}$ nanopure water) per $\mathrm{mL}$ of urine was added. First, a pool of urine samples was prepared by adding $0.5 \mathrm{mg}$ urine creatinine equivalent of urine (average urine volume $7.0 \pm 2.3 \mathrm{~mL}$ ) to each pool of AR, BK, and CAI. An equal volume of $1 \times$ PBS buffer was added to the urine. The urine was centrifuged at $2500 \times g$ for $15 \mathrm{~min}$ at $25^{\circ} \mathrm{C}$ and transferred to high-speed tubes and then centrifuged at $17,000 \times g$ for $30 \mathrm{~min}$ at $25^{\circ} \mathrm{C}$. The supernatant was transferred to a PBS buffer equilibrated nanomembrane concentrator (Vivaspin 20-PES 100,000 MWCO; VS2041) and centrifuged at $3000 \times g$ at $25^{\circ} \mathrm{C}$ for $30 \mathrm{~min}$. The filtrate was saved for separate analysis. The retentate was washed with $20 \mathrm{~mL}$ of PBS by centrifuging at $3000 \times g$ at $25^{\circ} \mathrm{C}$ for $20 \mathrm{~min}$. The volume of the retentate was adjusted to $200 \mu \mathrm{L}$ for downstream proteomic analysis.

\section{ONE-DIMENSIONAL, DENATURING, REDUCING ELECTROPHORESIS, AND IMMUNOBLOTTING}

Exosomal proteins $(5-20 \mu \mathrm{g})$ were separated using SDS-PAGE on $4-12 \%$ NuPAGE gels (Invitrogen) at $200 \mathrm{~V}$ until the bromophenol blue running dye migrated to the end of the gel using Mark12 molecular weight standards (Life Technologies, Carlsbad, CA, USA) and HK2 cell lysates or total urine protein as positive controls when possible. Proteins were electro-blotted and probed using previously published methods (14). Primary antibody $(0.2-1.0 \mu \mathrm{g} / \mathrm{mL})$ and secondary antibody $(0.05-0.2 \mu \mathrm{g} / \mathrm{mL})$ were dissolved in $5 \% \mathrm{w} / \mathrm{v}$ bovine serum albumin (Sigma-Aldrich) in TTBS (Sigma-Aldrich). Secondary antibody conjugated with horse-radish peroxidase (HRP) was visualized using the Pierce SuperSignal ${ }^{\circledR}$ West Pico Chemiluminescent Substrate Kit. Membranes were used to expose $\mathrm{x}$-ray film and resulting images were developed, scanned, and bands quantified.

\section{TRANSMISSION ELECTRON MICROSCOPY OF WHOLE-MOUNTED EXOSOMES}

Exosome samples recovered in PBS were used for TEM characterization. Exosomes were pelleted by high-speed ultracentrifugation at $200,000 \times g$. PBS was removed by pipetting and $4 \%$ glutaraldehyde (Polysciences, Warrington, PA, USA) in PBS was layered onto the exosomal pellet. Exosomal-protein glutaraldehyde-crosslinking was allowed to proceed for $1 \mathrm{~h}$. The cross-linked pellet was submitted for TEM analysis. The cross-linked exosomes were dehydrated in graded ethanol and flat-embedded in LX-112 epoxy resin (Ladd Industries, Burlington, VT, USA). Selected areas were mounted on blocks, ultra-thin sections $(70-80 \mathrm{~nm}$, silver-gray interference color) were cut using a diamond knife (Diatome, Fort Washington, PA, USA), and sections collected on copper grids. The sections were stained with saturated solutions of uranyl acetate, rinsed and submitted for imaging using a Philips CM10 transmission electron microscope operating at $60 \mathrm{kV}$.

\section{QUANTITATIVE URINE EXOSOMAL PROTEOMICS BY USING ITRAO AND LC MS/MS}

All peptide samples were assayed with bicinchoninic acid (BCA) (Thermo Scientific, Rockford, IL, USA) to determine the protein concentration. An equal mass of protein $(20 \mu \mathrm{g})$ was collected from each sample and brought to a volume of $30 \mu \mathrm{L}$ using $0.5 \mathrm{M}$ triethylammonium bicarbonate (TEAB) (all chemicals purchased from Sigma-Aldrich, St. Louis, MO, USA, unless otherwise stated). 2,2,2-Trifluoroethanol was added to the samples for a final concentration of $50 \%$ TFE. The samples were sonicated in an ice-water bath for $1 \mathrm{~min}$ and incubated at $60^{\circ} \mathrm{C}$ for $2 \mathrm{~h}$ with gentle shaking at $300 \mathrm{rpm}$. The samples were then reduced with $2 \mathrm{mM}$ dithiothreitol (DTT) with incubation at $37^{\circ} \mathrm{C}$ for $1 \mathrm{~h}$ with gentle shaking at $300 \mathrm{rpm}$. Iodoacetamide was added to reach a final concentration of $40 \mathrm{mM}$ for alkylation and incubated in the dark at $37^{\circ} \mathrm{C}$ for $1 \mathrm{~h}$ with constant shaking. The samples were then diluted sevenfold using $0.5 \mathrm{M}$ TEAB and digested with trypsin [50:1 protein:trypsin $(\mathrm{w} / \mathrm{w})$ ] (Promega, Madison, WI, USA) at $37^{\circ} \mathrm{C}$ for $3 \mathrm{~h}$. To clean the peptides, $\mathrm{C}-18$ solid phase extraction (SPE) was performed using Supelco Discovery columns with a Gilson GX-274 ASPEC ${ }^{\text {тм }}$ system (Gilson Inc., Middleton, WI, USA) and eluted into a lowprotein binding $1.5 \mathrm{~mL}$ centrifuge tube. All samples were then dried in a speed-vac to $15 \mu \mathrm{L}$ and assayed with BCA to determine the peptide concentration.

\section{8-plex ITRAQ labeling}

The $\mathrm{pH}$ of each sample was measured and brought to $\sim \mathrm{pH} 8$ using $1 \mathrm{M}$ TEAB. Each vial of 8-plex iTRAQ reagent (AB Sciex, Framingham, MA, USA) was brought to room temperature. The reagents were pulse spun to ensure the contents were collected at the bottom and $60 \mu \mathrm{L}$ of isoproponal was added to each reagent vial. The reagents were thoroughly vortexed, spun down, and added to the appropriate sample. The reagent vials were rinsed with an additional $10 \mu \mathrm{L}$ of isopropanol and added to the samples. 
The iTRAQ reagents with 8 channels 114-121 were used to label 2 pooled AR samples with each split into 2 as duplicates, $2 \mathrm{BKV}$, and 2 CAI, respectively, for each 8-plex iTRAQ experiment. Three 8 -plex experiments were performed for the 24 pools from the 4 phenotypes. For the labeling reaction, the $\mathrm{pH}$ was above 7.8 and the organic concentration was at least $60 \%(\mathrm{v} / \mathrm{v})$. Each sample was vortexed and spun down to incubate at room temperature for $2 \mathrm{~h}$ at which time $100 \mu \mathrm{L}$ of nanopure water were added to hydrolyze the sample and incubated for an additional $30 \mathrm{~min}$. The samples were partially dried down in a speed-vac to remove the organic solvent and then pooled together and dried down to a volume of $\sim 100 \mu \mathrm{L}$. An SPE C18 OMIX tip (Agilent, Santa Clara, CA, USA) was used to clean the final sample for 2D-LC-MS/MS analysis.

\section{D-LC-MS/MS analysis}

The final 8-plex iTRAQ-labeled sample was subjected to 2D-LCMS/MS analysis (15). The 2D-LC system was custom-built using two Agilent 1200 nanoflow pumps and one 1200 capillary pump (Agilent Technologies). Use of dual trapping and reversed-phase columns allowed for parallel event coordination, allowing for fraction trapping and washing offline while analytical separation occurred on the other reversed-phase column. Columns were manufactured in-house by slurry packing media into fused silica (Polymicro Technologies Inc.) using a $1 \mathrm{~cm}$ sol-gel frit for media retention. First-dimension SCX column: $5 \mu \mathrm{m}$ PolySULFOETHYL-A (PolyLC Inc.), $15 \mathrm{~cm} \times 360 \mu \mathrm{m}$ od $\times 150 \mu \mathrm{m}$ id. Trapping columns: $5 \mu \mathrm{m}$ Jupiter C18 (Phenomenex), $4 \mathrm{~cm} \times 360 \mu \mathrm{m}$ od $\times 150 \mu \mathrm{m}$ id. Second-dimension reversed-phase columns: $3 \mu \mathrm{m}$ Jupiter C18 (Phenomenex), $35 \mathrm{~cm} \times 360 \mu \mathrm{m}$ od $\times 75 \mu \mathrm{m}$ id. Mobile phases consisted of $0.1 \mathrm{mM} \mathrm{NaH}_{2} \mathrm{PO}_{4}$ (A) and $0.3 \mathrm{M} \mathrm{NaH}_{2} \mathrm{PO}_{4}$ (B) for the firstdimension column and $0.1 \%$ formic acid in water $(\mathrm{A})$ and $0.1 \%$ formic acid ACN (B) for the second-dimension column. The SCX separation provided 15 fractions for the second-dimension reversed-phase gradient nanoLC-MS/MS with $20 \mu \mathrm{L}$ for each fraction.

Mass spectrometry analysis was performed on a Thermo Fisher Scientific LTQ-Orbitrap Velos MS (San Jose, CA, USA) using a $150 \mu \mathrm{m}$ od $\times 20 \mu \mathrm{m}$ id chemically etched fused-silica electrospray emitter (16). The SCX separation for 15 fractions was performed stepwise, each step taking $20 \mathrm{~min}$. Each fraction was trapped on C18 material and washed for 50 min using the second-dimension mobile phase A. The gradient was then started and 15 min later acquisition was started and continued for $100 \mathrm{~min}$ for each fraction. The heated capillary temperature and spray voltage were $350^{\circ} \mathrm{C}$ and $2.2 \mathrm{kV}$, respectively. Full MS spectra were recorded at a resolution of 30,000 (for ions at $\mathrm{m} / z$ 400) over the range of $\mathrm{m} / \mathrm{z}$ 400-2000 with an automated gain control (AGC) value of 1e6. MS/MS was performed in the data-dependent mode with an AGC target value of $3 \mathrm{e} 4$. The ten most abundant parent ions, excluding single charge states, were selected for MS/MS using high-energy collisional dissociation (HCD) with a normalized collision energy setting of $40 \%$. A dynamic exclusion time of $45 \mathrm{~s}$ was used.

\section{STATISTICAL ANALYSIS}

A fold change over the global normal was calculated for each protein in the soluble and exosomal fractions. Two tailed unpaired $t$-tests were performed with SPSS software to determine the significance of differences in fold change over global normal between Uw and Ue compartments and differences in fold change over the global normal between $\mathrm{AR}$ and no AR in the exosomal fraction.

\section{RESULTS}

\section{PATIENT DEMOGRAPHICS}

A total of 30 urine samples were collected from AR $(n=10)$ and $\mathrm{nAR}(n=20)$ patients. In the AR population, at time of sample collection, age ranged from 1.9 to 19.4 years of age (mean $=14.5$ years), $40 \%$ were female, $70 \%$ received deceased donor transplants, $30 \%$ were living related donors, serum creatinine ranged from 0.2 to $1.8 \mathrm{mg} / \mathrm{dL}$ (mean $=1.15 \mathrm{mg} / \mathrm{dL}$ ) with a calculated creatinine clearance (by the Schwartz equation) of 63 $206 \mathrm{~mL} / \mathrm{min} / 1.73 \mathrm{~m}^{2}$ (mean $\left.=95 \mathrm{~mL} / \mathrm{min} / 1.73 \mathrm{~m} 2\right)$. Primary kidney diseases included focal segmental glomerulosclerosis (FSGS, $30 \%)$, reflux nephropathy/obstructive uropathy (20\%), dysplasia (10\%), Alport's syndrome (10\%), lupus nephritis (10\%), and $20 \%$ were unknown. In the nAR population, at time of sample population, age ranged from 1.7 to 18.7 years of age (mean $=12.1$ years) $30 \%$ were female, $50 \%$ were deceased donors, and $50 \%$ were living related donor transplants, serum creatinine at time of collection ranged between 0.3 and $3.5 \mathrm{mg} / \mathrm{dL}($ mean $=1.2 \mathrm{mg} / \mathrm{dL})$ with a calculated creatinine clearance range of $20-167 \mathrm{~mL} / \mathrm{min} / 1.73 \mathrm{~m}^{2}$ $($ mean $=89 \mathrm{~mL} / \mathrm{min} / 1.73 \mathrm{~m} 2)$. Primary kidney diseases included reflux nephropathy/obstructive uropathy (25\%), unknown (20\%), FSGS (10\%), 1 patient had both reflux and FSGS, dysplasia (10\%), vasculitis (10\%), dysplasia (10\%), nephrotic syndrome $(10 \%)$, and the remainder with, Alport's syndrome, cortical necrosis, and non-focal glomerulosclerosis.

\section{URINE EXOSOME ISOLATION BY CENTRIFUGAL FILTRATION}

Several exosomal extraction methods have been reported previously and included ultracentrifugation $(2,17,18)$, nanomembrane concentrator (6), and immunoisolation $(19,20)$. We tested two methods that used ultracentrifugation and nanomembrane concentrator for this study. When we used $10 \mathrm{~mL}$ urine from three different urine samples, the ultracentrifugation method did not provide sufficient exosome protein extract $(16 \pm 9 \mu \mathrm{g} / \mathrm{mL}$ raw urine) for Western blot analysis (data not shown). Applying the nanomembrane concentrator method to isolate urine exosomes, did not require ultracentrifugation and provided much better exosomal yield in terms of total protein $(678 \pm 93 \mu \mathrm{g} / \mathrm{mL}$ raw urine $)$ from the same set of three urine samples. The $100 \mathrm{kDa}$ centrifugal concentrators were used to isolate urine exosomes that could be analyzed to verify for exosomal extract by Western blot and electron microscopy (Figure 1). Programed Cell Death 6 Interacting Protein (ALIX), Tumor Susceptibility 101 (TSG101), and Aquaporin (AQP) were selected as markers for exosome vesicles $(17,21)$ for the Western blot. The enriched exosomal extract was tested for both the filtrate and the retentate fraction from the concentrator (Figure 1A). As demonstrated by electron micrograph (EM) in Figure 1B, the exosomal extract contained exosomal vesicles. This method was performed with urine at room temperature that helped in minimizing the formation of Tamm-Horsfall protein aggregates that have been reported to be a major challenge 


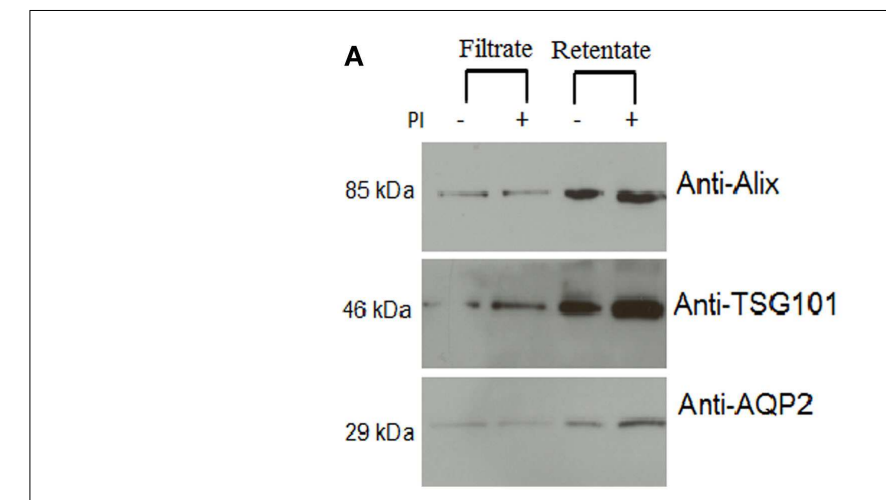

FIGURE 1 | Confirmation of isolation of exosomal vesicles from human urine. (A) Western blot demonstrated significant enrichment of exosomal marker proteins in the retentate fraction. From the image analysis, there was

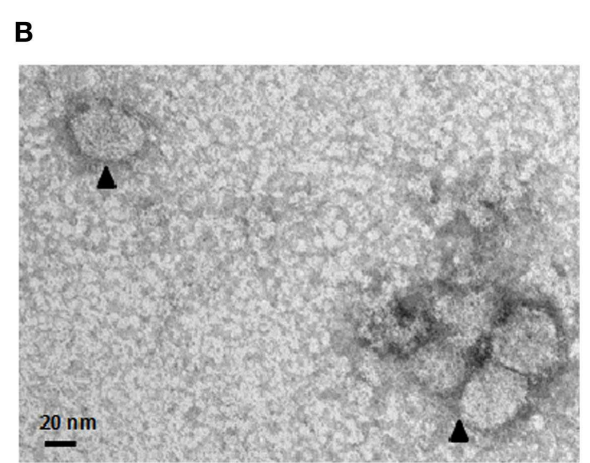

more retention of intact protein in the urine with added protease inhibitors than without added protease inhibitors. (B) Electron micrograph (EM) of isolated exosomes in the exosome extract. when using ultracentrifugation which needs to be carried out at $4^{\circ} \mathrm{C}(22)$.

\section{DETECTION OF NOVEL EXOSOMAL PROTEINS IN ACUTE REJECTION: EXPANSION OF THE URINE EXOSOME DATABASE}

2D-LC-MS/MS analyses of urine exosome samples resulted in the identification of a total of 349 proteins in the exosomal extract of which 343 proteins were identified in all injury phenotypes (Table S1 in Supplementary Material). We performed gene ontology (GO) analysis which revealed that these proteins were enriched in a number of biological pathways such as platelet degranulation $(p$-value $=8.07 \mathrm{e}-4)$ and activation $(p$ value $=7.39 \mathrm{e}-3)$, humoral immune response $(p$-value $=1.099 \mathrm{e}$ $9)$, complement activation $(p$-value $=2.410-9)$, and response to stress $(p$-value $=1.06 \mathrm{e}-4)$. GO molecular functions enriched are lipid transport $(p$-value $=1.979 \mathrm{e}-3)$, lipoprotein binding $(p$ value $=3.579 \mathrm{e}-4)$, and antioxidant activity $(p$-value $=5.049 \mathrm{e}-3)$. The cellular components enriched included blood extracellular components $(p$-value $=2.820 \mathrm{e}-21)$, cell surface components $(p$-value $=1.578 \mathrm{e}-8)$, blood mircoparticle $(p$-value $=2.769 \mathrm{e}-8)$, secretory granule lumen $(p$-value $=4.520 \mathrm{e}-8)$, and cytoplasmic membrane-bounded vesicle lumen $(p$-value $=7.849 \mathrm{e}-8)$. Evaluation of public domain data for urine proteins previously described in the Ue fraction of healthy subject control urine in both the ExoCarta database and published literature $(14,23)$ revealed that 220/349 Ue proteins in kidney transplant patients had not been previously identified in the healthy Ue fraction, indicative of unique Ue proteins in kidney transplant recipients. When we compared the 349 proteins to those previously identified in the whole urine proteome data set (13), 70 are unique to the exosomal fraction and 59 of these exclusive Ue proteins had not been previously identified (Figure 2). They mainly enriched for biological pathways related to cell mediated immunity and response to stress. The most significant molecular function was structural molecule activity and their cellular components were mainly extracellular or vesicle components. Twenty-five percent (18) of the proteins exclusive to the exosomal fraction were enriched for their higher expression in the renal cortex, based on our previous studies (24). High abundance urinary proteins, such as albumin and

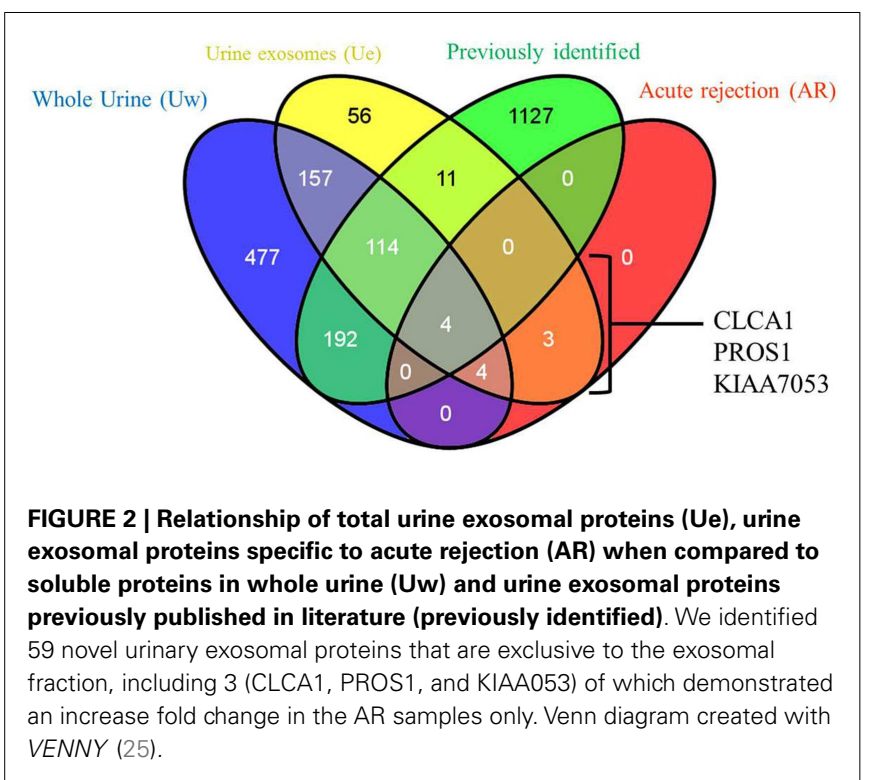

tubulin, were not enriched in high abundance in the Ue fraction (Figure 3).

\section{IDENTIFICATION OF AR-SPECIFIC URINE EXOSOMAL PROTEINS}

We quantitatively compared the abundance of the exosomal proteins in the $\mathrm{AR}$ urine to the exosomal proteins in the nAR urine using iTRAQ reagents. Eleven proteins namely Alpha-2-macroglobulin (A2M), Apolipoprotein A-II (APOA2), Apolipoprotein M (APOM), CD5 antigen-like (CD5L), calciumactivated chloride channel regulator-1 (CLCA1), fibrinogen alpha chain (FGA), fibrinogen beta chain (FGB), immunoglobulinmu chain $\mathrm{C}$ region (IGHM), defensin-5 (DEFA5), vitamin Kdependent protein S (PROS1), and protein KIAA0753(KIAA0753) were found to be increased in the exosomal fraction and significantly increased in the AR population (Figure 4; Table 1). Three of these proteins, calcium-activated chloride channel regulator 1, Protein S, and KIAA0753 were found exclusively in the exosomal fraction. They enriched for GO biological pathways such as 
platelet degranulation $(p$-value $=1.130 \mathrm{e}-8)$ and processes related to lipoprotein assembly and clearance $(p$-value $=1.130 \mathrm{e}-8)$. We performed two tailed $t$-tests of these proteins between Ue and Uw as well as AR and nAR. In the AR and nAR comparisons, DEFA5, a protein involved in the innate immune response, had

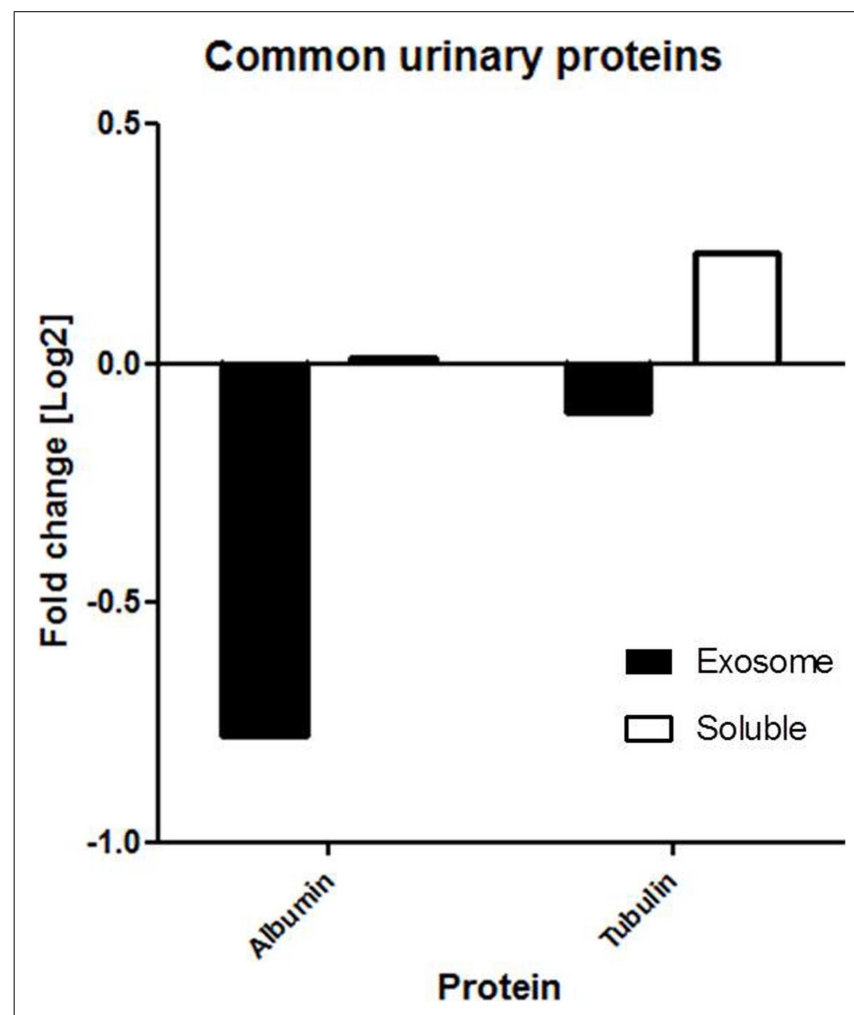

FIGURE 3 | Common proteins (e.g., albumin and tubulin) are not found in abundance in the exosomal fraction. Our findings show that the fold change of albumin and tubulin are much lower in the exosomal fraction than soluble fraction of urine. the greatest significant increase in $\operatorname{AR}(4.89 \pm 0.23, p=3.3 e-5)$, however, the difference in fold change in the Ue versus the Uw compartment was not significant. CLCA1 had the least significant increase in $\operatorname{AR}(p=0.052)$. Six urine exosomal proteins were previously unidentified. APOM is a component of kidney epithelial cells and has been previously linked to renal injury (26) but had not been previously identified as a urine exosomal protein. In our studies, we found it to be significantly increased in the exosomal fraction ( $p=0.022, \mathrm{CI}=1.15-2.88)$ and significantly increased in the AR population $(p=0.001, \mathrm{CI}=1.64-3.22)$. Three novel urine exosomal proteins, CLCA1, PROS1, and KIAA0753, were exclusively found in the AR population of renal transplants. CLCA1 is a $100 \mathrm{kDa}$ secreted membrane associated human protein typically found in mucus producing goblet cells. It is involved in mediating calcium-activated chloride conductance (27). There is evidence that it is involved in the regulation of tissue inflammation in the innate immune response (28). PROS1 codes for the $75 \mathrm{kDa}$ secreted human Protein S anticoagulant, which is a co-factor to activated protein $\mathrm{C}$ and is involved in the regulation of the coagulation cascade by degrading Factors Va and VIIIa. Thus, it is involved in blood coagulation and is associated with extracellular vesicles. Based on information from GeneCard, KIAA0753 encodes for a protein involved in ubiquination and protein degradation. Eight Ue AR-specific markers are detected in Uw, but as they are at much lower abundance levels in Uw, they are not significant for AR in Uw.

In this study, urinary neutrophil gelatinase-associated lipocalin (NGAL), which is a well-known urinary marker of kidney injury (29) and graft dysfunction (30), was not identified despite the fact that it has been reported to be detected in urine exosomes by ELISA (31) and also by us in the mass spectrometric analysis of soluble proteins in the urine (13). Another well-known urinary protein, kidney injury molecule (KIM1) (32) was not identified in this study but has been identified in the soluble urinary fraction of urine collected from kidney transplantation patients (data not shown). The absence of the well-known markers from our list of 349 urine exosomal proteins is attributed to the fact that their

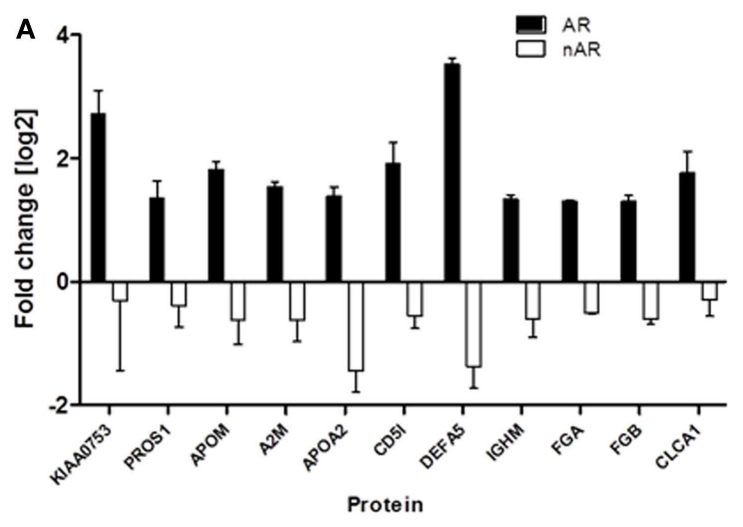

FIGURE 4 | (A) Urine from patients in the acute rejection population enriched for eleven exosomal proteins with an increased fold change over the whole urine fraction. All, except CLCA1, have significantly ( $p$-values $<0.05$ ) increased fold change in the Ue of AR when compared to Ue of

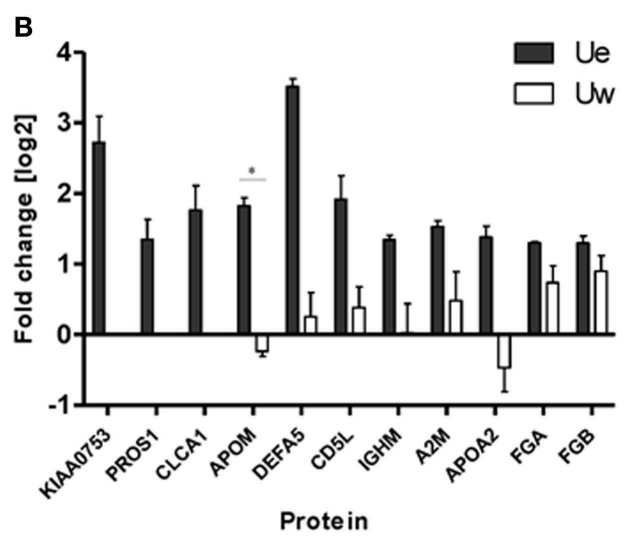

nAR. (B) They are also enriched in Ue over Uw. CLCA1, PROS1, and KIAA0753 were detected in the exosomal fraction only, however, there is only significantly increased enrichment $\left(^{*}\right)$ was observed for ApoM $(p=0.02)$. 
Table 1 | AR exosomal proteins

\begin{tabular}{|c|c|c|c|c|c|c|c|c|c|}
\hline \multirow[t]{2}{*}{ Gene ID } & \multirow[t]{2}{*}{ Description } & \multirow[t]{2}{*}{ Function } & \multirow[t]{2}{*}{$\begin{array}{l}\text { GO biological } \\
\text { processes }\end{array}$} & \multirow[t]{2}{*}{$\begin{array}{l}\text { GO cellular } \\
\text { components }\end{array}$} & \multicolumn{3}{|c|}{$\begin{array}{l}\text { Average fold change: } \\
\text { (nd, not detected) }\end{array}$} & \multicolumn{2}{|c|}{$\begin{array}{l}\text { Fold change: } \\
\text { Ue (AR)-Ue (nAR) }\end{array}$} \\
\hline & & & & & Ue & Uw & $p$ & $\Delta$ & $p$ \\
\hline DEFA5 & $\begin{array}{l}\text { Defensin, alpha 5, } \\
\text { Paneth } \\
\text { cell-specific }\end{array}$ & $\begin{array}{l}\text { Antimicrobial } \\
\text { activity possibly via } \\
\text { membrane } \\
\text { permeabilization }\end{array}$ & $\begin{array}{l}\text { Antibacterial } \\
\text { response; humoral } \\
\text { and innate response }\end{array}$ & $\begin{array}{l}\text { Extracellular; Golgi } \\
\text { lumen; cytoplasmic } \\
\text { vesicle }\end{array}$ & 3.52 & 0.51 & 0.22 & 4.89 & $3.36 e-05$ \\
\hline KIAA0 753 & $109 \mathrm{kDa}$ protein & $\begin{array}{l}\text { Uncharacterized } \\
\text { protein, associated } \\
\text { with protein } \\
\text { degradation }\end{array}$ & $\mathrm{n} / \mathrm{a}$ & $\begin{array}{l}\text { Cytoplasm; } \\
\text { centrosome }\end{array}$ & 2.50 & nd & $\mathrm{n} / \mathrm{a}$ & 3.03 & 0.055 \\
\hline CLCA1 & $\begin{array}{l}\text { Calcium-activated } \\
\text { chloride channel } \\
\text { regulator } 1\end{array}$ & $\begin{array}{l}\text { May mediate } \\
\text { calcium-activated } \\
\text { chloride } \\
\text { conductance; } \\
\text { associated with } \\
\text { immune response } \\
\text { and inflammation }\end{array}$ & $\begin{array}{l}\text { Calcium ion and } \\
\text { chloride transport; } \\
\text { cellular response to } \\
\text { hypoxia }\end{array}$ & $\begin{array}{l}\text { Extracellular; } \\
\text { plasma membrane; } \\
\text { microvillus }\end{array}$ & 1.76 & nd & $\mathrm{n} / \mathrm{a}$ & 2.06 & 0.052 \\
\hline APOA2 & $\begin{array}{l}\text { Apolipoprotein } \\
\text { A-II }\end{array}$ & May stabilize HDL & $\begin{array}{l}\text { Acute inflammatory } \\
\text { response; cholesterol } \\
\text { homeostasis, } \\
\text { transport, and } \\
\text { assembly; host virus } \\
\text { interaction }\end{array}$ & $\begin{array}{l}\text { Chylomicron; } \\
\text { endoplasmic } \\
\text { reticulum lumen; } \\
\text { extracellular; } \\
\text { HDLNLDL particle }\end{array}$ & 1.38 & -0.47 & 0.28 & 2.83 & 0.001 \\
\hline PROS1 & $\begin{array}{l}\text { Vitamin } \\
\text { K-dependent } \\
\text { protein S }\end{array}$ & $\begin{array}{l}\text { Activated protein C } \\
\text { co-factor, degrades } \\
\text { factors Va and VIIla; } \\
\text { stimulates } \\
\text { fibrinolysis }\end{array}$ & $\begin{array}{l}\text { Anticoagulation; } \\
\text { leukocyte migration } \\
\text { and immune response }\end{array}$ & $\begin{array}{l}\text { Extracellular; Golgi } \\
\text { membrane }\end{array}$ & 1.35 & nd & $n / a$ & 1.74 & 0.023 \\
\hline IGHM & $\begin{array}{l}\text { Immunoglobulin } \\
\text { heavy constant } \\
\text { mu }\end{array}$ & $\begin{array}{l}\text { Constant region of } \\
\text { lgM, a soluble and } \\
\text { membrane bound } \\
\text { antibody }\end{array}$ & $\begin{array}{l}\text { Immune response; } \\
\text { antibacterial immune } \\
\text { response }\end{array}$ & $\begin{array}{l}\text { Extracellular; } \\
\text { plasma membrane } \\
\text { bound }\end{array}$ & 1.34 & 0.22 & 0.41 & 1.95 & 0.006 \\
\hline
\end{tabular}


Table 1 | Continued

\begin{tabular}{|c|c|c|c|c|c|c|c|c|c|}
\hline \multirow[t]{2}{*}{ Gene ID } & \multirow[t]{2}{*}{ Description } & \multirow[t]{2}{*}{ Function } & \multirow[t]{2}{*}{$\begin{array}{l}\text { GO biological } \\
\text { processes }\end{array}$} & \multirow[t]{2}{*}{$\begin{array}{l}\text { GO cellular } \\
\text { components }\end{array}$} & \multicolumn{3}{|c|}{$\begin{array}{l}\text { Average fold change: } \\
\text { (nd, not detected) }\end{array}$} & \multicolumn{2}{|c|}{$\begin{array}{l}\text { Fold change: } \\
\text { Ue (AR)-Ue (nAR) }\end{array}$} \\
\hline & & & & & Ue & Uw & $p$ & $\Delta$ & $p$ \\
\hline FGA & $\begin{array}{l}\text { Fibrinogen alpha } \\
\text { chain }\end{array}$ & $\begin{array}{l}\text { Component of } \\
\text { fibrinogen for } \\
\text { platelet } \\
\text { aggregation }\end{array}$ & $\begin{array}{l}\text { Coagulation; platelet } \\
\text { activation and platelet } \\
\text { degranulation; signal } \\
\text { transduction }\end{array}$ & $\begin{array}{l}\text { Extracellular; } \\
\text { plasma membrane; } \\
\text { extracellular } \\
\text { vesicles; fibrinogen } \\
\text { complex }\end{array}$ & 1.3 & 0.73 & 0.06 & 1.81 & 0.006 \\
\hline FGB & $\begin{array}{l}\text { Fibrinogen beta } \\
\text { chain }\end{array}$ & $\begin{array}{l}\text { Component of } \\
\text { fibrinogen for } \\
\text { platelet } \\
\text { aggregation }\end{array}$ & $\begin{array}{l}\text { Coagulation; platelet } \\
\text { activation and } \\
\text { degranulation; signal } \\
\text { transduction }\end{array}$ & & 1.3 & 0.9 & 0.16 & 1.90 & 0.006 \\
\hline
\end{tabular}

lower abundance in the urine and the dependence of unbiased identification by a quantitative MS method, such as ITRAQ, on protein abundance is biased toward proteins that are enriched in the study sample (urine exosome) in this case.

\section{DISCUSSION}

Because of the potential of exosomes containing enriched candidate biomarkers for diseases there is a growing interest in exosome isolation and investigation of its compositions. It has been shown that exosomes are shed in urine and contain membrane bound proteins and proteins involved in cell signaling, inflammation, and originate from renal epithelial cells $(2,23)$. Previous studies have shown that urine exosomes were enriched in innate immune modulators, but there have not been studies that describe the enrichment of exosomes in transplant injury compared to normal in solid organ transplantation. Our Uexo extraction and purification method is not only simple but is also readily transferrable to other clinical labs.

We observe an enrichment of exosome specific proteins in kidney transplant patients who have biopsy proven AR, and perturbation in the Ue fraction by disease resulted in a repertoire very different from the Ue fraction in normal health. In fact, only $9 \%$ of the Ue proteins detected in healthy urine were noted in the Ue fraction from patents with renal transplants, and most of these overlapping Ue proteins are involved in vesicle-mediated transport $(p=2.109 \mathrm{e}-14)$, regulatory mechanisms $(2.109 \mathrm{e}-14)$, and response to stress $(p=1.060 \mathrm{e}-13)$. In kidney transplantation, the ischemic and alloimmune injury to the donor kidney resulted in marked changes in the Ue fraction, with an enrichment of proteins involved in inflammation, cell division, tissue repair, and the immune response. AR creates an environment of inflammation of the renal tubule (the tubulits injury in AR), interstitium, and the vascular space and the altered response of the injured tubules to these infiltrating cells is seen by a predominance of proteins involved in cell repair $(p=0.037)$ and fibrosis $(p=0.03)$.

The orchestrated injury and its local response in transplant rejection is highly specific and likely explains the almost complete alteration of the Ue fraction in urine samples taken from organ transplant patients versus normal healthy volunteers. The highly specific nature of the perturbations of the Ue compartment in disease, make the study of this space very attractive in terms of studying disease and injury mechanism. Additionally, as these altered protein fractions mirror the local organ injury, monitoring for changes in the abundance of these proteins could be tracked as sensitive disease and injury specific biomarkers. Our studies indicate that the Ue-specific AR biomarkers in this pilot study are highly specific for AR versus other types of transplant injury, and can only be identified by Ue analysis due to their very low abundance or even complete absence from similar analysis of unfractionated whole urine.

Within this compartment, we identified proteins (CLCA1, PROS1, and KIAA0753) that are exclusive to AR patients and have not been previously identified in the available databases of healthy urine exosomal proteins. Since these proteins are enriched in inflammatory responses, they may serve as valuable useful markers of rejection. Also, within this compartment is ApoM, which has been previously identified to in soluble urine and associated with kidney injury. We show that exosomal ApoM is more abundant than soluble ApoM thus supporting that exosomal proteins could serve as a more sensitive biomarker. Numerous studies, including those originating from our group have shown that using elevated creatinine and biopsy results to identify renal transplant dysfunction and rejection is often a late finding (33-36). Further studies are needed to evaluate if the Ue-specific proteins in AR, are altered earlier in the course of rejection injury, and if their altered detection, when altered, can predate a rise in the serum creatinine providing the potential for early intervention and prompt injury reversal.

In conclusion, in this report, we have optimized a rapid urinary exosome isolation method and quantitative measurement of enriched Ue proteins. Our observation from this study demonstrated that proteins in the exosomal compartment of urine collected from kidney transplant patients were specific to inflammatory responses, which were different from normal healthy subjects. However, the small sample size of the study and because of the possibility of $>100 \mathrm{kDa}$ proteins isolation due to the cutoff size of the nanomembrane concentrater, future studies with larger sample size and further refinement in the exosomal method is warranted. 


\section{ACKNOWLEDGMENTS}

The authors acknowledge the funding support from NIDDK R01DK083447 (to Minnie M. Sarwal and David G. Camp II) and P41GM103493 (to Richard D. Smith). The proteomics work described herein was performed in the Environmental Molecular Sciences Laboratory (EMSL), a U.S. Department of Energy (DOE) national scientific user facility located at PNNL in Richland, Washington. PNNL is a multi-program national laboratory operated by Battelle Memorial Institute for the DOE under Contract DE-AC05-76RL01830.

\section{SUPPLEMENTARY MATERIAL}

The Supplementary Material for this article can be found online at http://www.frontiersin.org/Journal/10.3389/fmed.2014.00057/ abstract

\section{REFERENCES}

1. Racusen LC, Solez K, Colvin RB, Bonsib SM, Castro MC, Cavallo T, et al. The Banff 97 working classification of renal allograft pathology. Kidney Int (1999) 55(2):713-23. doi:10.1046/j.1523-1755.1999.00299.x

2. Gonzales PA, Pisitkun T, Hoffert JD, Tchapyjnikov D, Star RA, Kleta R, et al. Large-scale proteomics and phosphoproteomics of urinary exosomes. J Am Soc Nephrol (2009) 20(2):363-79. doi:10.1681/ASN.2008040406

3. Utleg AG, Yi EC, Xie T, Shannon P, White JT, Goodlett DR, et al. Proteomic analysis of human prostasomes. Prostate (2003) 56(2):150-61. doi:10.1002/pros. 10255

4. Smalley DM, Sheman NE, Nelson K, Theodorescu D. Isolation and identification of potential urinary microparticle biomarkers of bladder cancer. J Proteome Res (2008) 7(5):2088-96. doi:10.1021/pr700775x

5. Miranda KC, Bond DT, McKee M, Skog J, Păunescu TG, Da Silva N, et al. Nucleic acids within urinary exosomes/microvesicles are potential biomarkers for renal disease. Kidney Int (2010) 78(2):191-9. doi:10.1038/ki.2010.106

6. Cheruvanky A, Zhou H, Pisitkun T, Kopp JB, Knepper MA, Yuen PS, et al. Rapid isolation of urinary exosomal biomarkers using a nanomembrane ultrafiltration concentrator. Am J Physiol Renal Physiol (2007) 292(5):F1657-61. doi:10.1152/ajprenal.00434.2006

7. Merchant ML, Powell DW, Wilkey DW, Cummins TD, Deegens JK, Rood IM, et al. Microfiltration isolation of human urinary exosomes for characterization by MS. Proteomics Clin Appl (2010) 4(1):84-96. doi:10.1002/prca.200800093

8. Racusen LC, Halloran PF, Solez K. Banff 2003 meeting report: new diagnostic insights and standards. Am J Transplant (2004) 4(10):1562-6. doi:10.1111/j. 1600-6143.2004.00585.x

9. Solez K, Colvin RB, Racusen LC, Haas M, Sis B, Mengel M, et al. Banff 07 classification of renal allograft pathology: updates and future directions. Am J Transplant (2008) 8(4):753-60. doi:10.1111/j.1600-6143.2008.02159.x

10. Solez K, Colvin RB, Racusen LC, Sis B, Halloran PF, Birk PE, et al. Banff' '05 meeting report: differential diagnosis of chronic allograft injury and elimination of chronic allograft nephropathy ('CAN'). Am J Transplant (2007) 7(3):518-26. doi:10.1111/j.1600-6143.2006.01688.x

11. Li L, Chaudhuri A, Chen A, Zhao X, Bezchinsky M, Concepcion W, et al. Efficacy and safety of thymoglobulin induction as an alternative approach for steroidfree maintenance immunosuppression in pediatric renal transplantation. Transplantation (2010) 90(12):1516-20. doi:10.1097/TP.0b013e3181fc8937

12. Sigdel TK, Lau K, Schilling J, Sarwal M. Optimizing protein recovery for urinary proteomics, a tool to monitor renal transplantation. Clin Transplant (2008) 22(5):617-23. doi:10.1111/j.1399-0012.2008.00833.x

13. Sigdel TK, Salomonis N, Nicora CD, Ryu S, He J, Dinh V, et al. The identification of novel potential injury mechanisms and candidate biomarkers in renal allograft rejection by quantitative proteomics. Mol Cell Proteomics (2014) 13(2):621-31. doi:10.1074/mcp.M113.030577

14. Gonzales PA, Zhou H, Pisitkun T, Wang NS, Star RA, Knepper MA, et al. Isolation and purification of exosomes in urine. Methods Mol Biol (2010) 641:89-99. doi:10.1007/978-1-60761-711-2_6

15. Smith JS, Angel TE, Chavkin C, Orton DJ, Moore RJ, Smith RD. Characterization of individual mouse cerebrospinal fluid proteomes. Proteomics (2014) 14(9):1102-6. doi:10.1002/pmic.201300241
16. Kelly RT, Page JS, Luo Q, Moore RJ, Orton DJ, Tang K, et al. Chemically etched open tubular and monolithic emitters for nanoelectrospray ionization mass spectrometry. Anal Chem (2006) 78(22):7796-801. doi:10.1021/ac061133r

17. Pisitkun T, Shen RF, Knepper MA. Identification and proteomic profiling of exosomes in human urine. Proc Natl Acad Sci U S A (2004) 101(36):13368-73. doi:10.1073/pnas.0403453101

18. Duijvesz D, Burnum-Johnson KE, Gritsenko MA, Hoogland AM, Vredenbregtvan denBerg MS, Willemsen R, et al. Proteomic profiling of exosomes leads to the identification of novel biomarkers for prostate cancer. PLoS One (2013) 8(12):e82589. doi:10.1371/journal.pone.0082589

19. Caby MP, Lankar D, Vincendeau-Scherrer C, Raposo G, Bonnerot C. Exosomallike vesicles are present in human blood plasma. Int Immunol (2005) 17(7):879-87. doi:10.1093/intimm/dxh267

20. Wubbolts R, Leckie RS, Veenhuizen PT, Schwarzmann G, Möbius W, Hoernschemeyer J, et al. Proteomic and biochemical analyses of human B cellderived exosomes. Potential implications for their function and multivesicular body formation. J Biol Chem (2003) 278(13):10963-72. doi:10.1074/jbc. M207550200

21. Zhou H, Yuen PS, Pisitkun T, Gonzales PA, Yasuda H, Dear JW, et al. Collection, storage, preservation, and normalization of human urinary exosomes for biomarker discovery. Kidney Int (2006) 69(8):1471-6. doi:10.1038/sj.ki.5000273

22. Fernández-Llama P, Khositseth S, Gonzales PA, Star RA, Pisitkun T, Knepper MA. Tamm-Horsfall protein and urinary exosome isolation. Kidney Int (2010) 77(8):736-42. doi:10.1038/ki.2009.550

23. Hiemstra TF, Charles PD, Gracia T, Hester SS, Gatto L, Al-Lamki R, et al. Human urinary exosomes as innate immune effectors. J Am Soc Nephrol (2014) 25(9):2017-27. doi:10.1681/ASN.2013101066

24. Li L, Sigdel T, Vitalone M, Lee SH, Sarwal M. Differential immunogenicity and clinical relevance of kidney compartment specific antigens after renal transplantation. J Proteome Res (2010) 9(12):6715-21. doi:10.1021/pr1008674

25. Oliveros JC. VENNY. An Interactive Tool for Comparing Lists with Venn Diagrams (2007). Available from: http://bioinfogp.cnb.csic.es/tools/venny/index.html

26. Xu XL, Mao QY, Luo GH, Nilsson-Ehle P, He XZ, Xu N. Urinary apolipoprotein $M$ could be used as a biomarker of acute renal injury: an ischemiareperfusion injury model of kidney in rat. Transplant Proc (2013) 45(6):2476-9. doi:10.1016/j.transproceed.2013.04.009

27. Gruber AD, Elble RC, Ji HL, Schreur KD, Fuller CM, Pauli BU. Genomic cloning, molecular characterization, and functional analysis of human CLCA1, the first human member of the family of $\mathrm{Ca} 2+$-activated $\mathrm{Cl}$ - channel proteins. Genomics (1998) 54(2):200-14. doi:10.1006/geno.1998.5562

28. Hoshino M, Morita S, Iwashita H, Sagiya Y, Nagi T, Nakanishi A, et al. Increased expression of the human $\mathrm{Ca} 2+$-activated $\mathrm{Cl}$ - channel 1 ( $\mathrm{CaCC} 1$ ) gene in the asthmatic airway. Am J Respir Crit Care Med (2002) 165(8):1132-6. doi:10.1164/ajrccm.165.8.2107068

29. Gagneux-Brunon A, Delanaye P, Legrand D, Cavalier E, Mariat C. [NGAL, biomarker of acute kidney injury in 2012]. Nephrol Ther (2012) 8(7):508-15. doi:10.1016/j.nephro.2012.03.006

30. Heyne N, Kemmner S, Schneider C, Nadalin S, Königsrainer A, Häring HU. Urinary neutrophil gelatinase-associated lipocalin accurately detects acute allograft rejection among other causes of acute kidney injury in renal allograft recipients. Transplantation (2012) 93(12):1252-7. doi:10.1097/TP.0b013e31824fd892

31. Alvarez S, Suazo C, Boltansky A, Ursu M, Carvajal D, Innocenti G, et al. Urinary exosomes as a source of kidney dysfunction biomarker in renal transplantation. Transplant Proc (2013) 45(10):3719-23. doi:10.1016/j.transproceed. 2013.08.079

32. Han WK, Bailly V, Abichandani R, Thadhani R, Bonventre JV. Kidney injury molecule-1 (KIM-1): a novel biomarker for human renal proximal tubule injury. Kidney Int (2002) 62(1):237-44. doi:10.1046/j.1523-1755.2002.00433.x

33. Sarwal M, Sigdel T. A common blood gene assay predates clinical and histological rejection in kidney and heart allografts. Clin Transpl (2013):241-7.

34. Li L, Khatri P, Sigdel TK, Tran T, Ying L, Vitalone MJ, et al. A peripheral blood diagnostic test for acute rejection in renal transplantation. Am J Transplant (2012) 12(10):2710-8. doi:10.1111/j.1600-6143.2012.04253.x

35. Naesens M, Khatri P, Li L, Sigdel TK, Vitalone MJ, Chen R, et al. Progressive histological damage in renal allografts is associated with expression of innate and adaptive immunity genes. Kidney Int (2011) 80(12):1364-76. doi:10.1038/ki.2011.245

36. Naesens M, Salvatierra O, Benfield M, Ettenger RB, Dharnidharka V, Harmon W, et al. Subclinical inflammation and chronic renal allograft injury in 
a randomized trial on steroid avoidance in pediatric kidney transplantation. Am J Transplant (2012) 12(10):2730-43. doi:10.1111/j.1600-6143.2012.04144.x

Conflict of Interest Statement: The authors declare that the research was conducted in the absence of any commercial or financial relationships that could be construed as a potential conflict of interest.

Received: 25 October 2014; accepted: 11 December 2014; published online: 05 January 2015.
Citation: Sigdel TK, Ng YW, Lee S, Nicora CD, Qian W-J, Smith RD, Camp DG II and Sarwal MM (2015) Perturbations in the urinary exosome in transplant rejection. Front. Med. 1:57. doi: 10.3389/fmed.2014.00057

This article was submitted to Nephrology, a section of the journal Frontiers in Medicine. Copyright $\odot 2015$ Sigdel, Ng, Lee, Nicora, Qian, Smith, Camp and Sarwal. This is an open-access article distributed under the terms of the Creative Commons Attribution License (CC BY). The use, distribution or reproduction in other forums is permitted, provided the original author(s) or licensor are credited and that the original publication in this journal is cited, in accordance with accepted academic practice. No use, distribution or reproduction is permitted which does not comply with these terms. 